\title{
IMPROVING THE LISTENING COMPREHENSION OF THE FIRST YEAR STUDENTS OF A STATE SENIOR HIGH SCHOOL IN ENREKANG, INDONESIA
}

\author{
Ita Sarmita Samad \\ Email: itaneverendita@gmail.com \\ STKIP Muhammadiyah Enrekang, Indonesia
}

\begin{abstract}
This study aims at finding out whether or not the implementation of jigsaw listening improves the Listening comprehension of the first year students of a state senior high school in Enrekang. This study employs a quasi experimental method. The population of this study is the first year students of a state senior high school in Enrekang in the academic year 2012/2013. It uses random sampling, taking two classes totalling 52 students. It involves two groups, namely experimental class and control class. The students' pre-test and post-test shows that there is significance different between experimental and control group. The result of the gained of mean score shows the difference between those groups. The difference of the mean score of pre-test and posttest of experimental group is 16.62 while control group is 0.73 . It means that $\overline{X_{A}}>$ $\overline{X_{B}}(16.62>0.73)$. The students of experimental group get better improvement than the students' of control group. Thus, it can be concluded that the hypothesis is tenable. Besides, the t-test value of gained score (2.65) is higher than t-table (2.021). Thus, it can be concluded that the jigsaw listening improves the students' listening comprehension.
\end{abstract}

\section{Keywords: Jigsaw, Listening Comprehension, EFL Learners, Teaching Technique}

\section{INTRODUCTION}

Listening is a skill in which people do not just hear something through their ears but also have to understand, remember, and respond what they have heard. In terms of language learning, listening means the students are able to understand what the speakers are saying. Then, they can express their understanding through either written or oral expression.

EFL students need to improve their listening skill. It is because this skill can affect the other English skills. By improving their listening skill, the students will be accustomed to listen to the correct sentences by the native speaker. Automatically, it influences the students' grammar ability and writing skill as well. Besides, listening to the new vocabularies will also influence their reading skill.

However, most of students in Indonesia face some difficulties in improving this skill. It is not surprise since English is not their mother tongue. Thus, they are not accustomed to listen to the English native speakers. Furthermore, it is because a lack of listening practice in the EFL class. According to the researcher's experience when she was either in junior

\#\# HowToCite\#\#

I. Sarmita. S. (2018). Improving the Listening Comprehension of the First Year Students of A State Senior High School in Enrekang, Indonesia. Edumaspul - Jurnal Pendidikan, 2(2), 22-26 
or senior high school, she was just taught listening when it was at the end of semester or almost about one month before the final test. In addition, the lack of facilities and techniques of teaching and learning English in school are causing the listening comprehension is difficult to improve.

Consequently, it needs to find some interesting teaching techniques which can motivate the students to learn and practice more. Jigsaw listening could be one of them. Harmer (2007:10) says that the students will get motivation to be more creative and enthusiastic in learning English especially listening when they are taught through jigsaw listening.

This study is intended to know whether or not the implementation of jigsaw listening can improve the students' listening comprehension.

\section{LITERATURE REVIEW}

\section{Previous Related Studies}

Some studies show that the use of jigsaw can improve students' English comprehension. Atmarani (2011) finds that the technique can create the effective situation for students of the $\mathrm{X}$ grade in SMAN 2 Parepare. Another similar study proves that it could improve students' reading comprehension (Eka, 2011). The study conducted by Fitri (2011) shows that jigsaw technique can enhance English speaking skill of the eight grade students of SMPN 1 Takalar.

\section{Some Pertinent Ideas}

\section{Listening Comprehension}

Wipf (1984) defines listening as a mental process. In this process, the listeners are trying to distinguish the sounds, to understand the vocabularies and structures, and to figure out the stress and intonation all at once. According to Rost
(2002), listening consists of four stages. They are receptive, constructive, collaborative, and transformative orientation. Steinburg (2007) stated that listening is a process that more complex than merely hearing. It consists of four stages; sensing and attending, understanding and interpreting, remembering, and responding. Thus, It can be concluded that listening is a process consisting of hearing something through the ears, understanding the meaning, negotiating the intended meaning/ message, and finally responding of what have listened.

Harmer (2007:10:134) divides listening into two types. They are iintensive and extensive listening. He distinguishes the types specifically based on its purpose. It is called as iintensive listening when the students' purpose of listening is to work on listening skills. Meanwhile, It is called as extensive listening when listening is done in order to study the way in which English is spoken.

In terms of listening in the classroom, Cooper (2012) divided listening into 4 types. They are critical, dialogic, informative, and appreciative listening. Critical listening is also known as analytical listening. The purpose is to form an opinion or to judge. Dialogic listening is also considered as emphatic or active listening. It is when the students do the listening trough conversation and ideas exchange. It is called iinformative when it is used to understand or comprehend what the intended meaning of the utternces. Appreciative listening is when the students enjoy or appreciates what lecturer or their teacher is talking about.

\section{Jigsaw Listening}

Harmer (2007:10) defines jigsaw listening as a cooperative learning technique in teaching listening in which the students are divided into some groups namely jigsaw group. Each student of each 
jigsaw group is assigned to different segment of a story. After hearing the story, each student who has the same assignment (segment) will be gathered in temporary group namely expert group in order to discuss their segment. Finally, the students are gathered again in their jigsaw group to discuss what actually the story talk about. Thus, it can encourage the students to be more creative and to be more interested in learning English.

\section{Participants}

The participants in this study were chosen randomly. The writer chose the students of a state senior high school in Enrekang. Class X.D was chosen as the experimental group and class X.C was chosen as the control group. Each group consists of 26 students.

\section{Data Collection}

Pre-test. Both of experimental and control group was given a pre-test. Its aim is to get the students' score before giving them different treatment. The test given is a kind of filling the gap. The audio turned twice and the students had to fill the gap in the text provided. It ran for 60 minutes.

Post-test. Both of control and experimental group was given a post test. It is to recognize the result of the treatment and to compare with the pre-test. Thus, It would be identified whether the jigsaw listening can improve students' listening comprehension or not.

\section{FINDING AND DISCUSSION}

The following table is the statistical summary of the students' pretest and posttest

score.

Table 1 the Rate Percentage of Students' Pre-test and post-test Score

\begin{tabular}{llcccccccc}
\hline & & \multicolumn{4}{c}{ Pre-Test } & \multicolumn{4}{c}{ Post-Test } \\
\cline { 3 - 10 } No & Classification & $\begin{array}{c}\text { Experimental } \\
\text { Class }\end{array}$ & Control Class & $\begin{array}{c}\text { Experimental } \\
\text { Class }\end{array}$ & Control Class \\
\cline { 2 - 11 } & & F & $\mathbf{\%}$ & F & \% & F & \% & F & \% \\
\hline 1 & Very good & 0 & 0 & 0 & 0 & 0 & 0 & 0 & 0 \\
\hline 2 & Good & 0 & 0 & 10 & 38 & 1 & 4 & 9 & 35 \\
\hline 3 & Fair & 0 & 0 & 16 & 62 & 4 & 15 & 17 & 65 \\
\hline 4 & Poor & 7 & 27 & 0 & 0 & 7 & 27 & 0 & 0 \\
\hline 5 & Very poor & 19 & 73 & 0 & 0 & 14 & 54 & 0 & 0 \\
\hline & Total & 26 & 100 & 26 & 100 & 26 & 100 & 26 & 100 \\
\hline
\end{tabular}

Table above shows that before giving treatment, there are 19 students who get very poor score and 7 students who get poor score. There is no student who gets very good, good, and fair score. In control class, the table shows that there are 10 students who get good score and 16 students who get fair scores. There is no student who gets very good, poor and very poor score.
However, after giving the treatment, there is 1 of 26 students who gets good score, 4 students get fair score, 8 students get poor score and 13 of them who get very poor score. There is no student gets very good score. For the control class, 9 out of 26 students get good score and 17 students get fair score. There is no student who gets very good, poor and very poor score. 
It can be concluded that the students in control group still got higher score than students in experimental group. However, in terms of number of students whose score is improved, the experimental group still has a better performance. By comparing the students' pretest and posttest score, it finds out that the number of the students from experimental group who get higher score in their post test is more than the control group does.

After calculating the result of the students' pretest and posttest, the mean score and standard deviation of both groups are presented in following table:

Table 2.Mean Score and Standard Deviation of the Students' Score

\begin{tabular}{cccccc}
\hline \multirow{2}{*}{ Group } & \multicolumn{2}{c}{ Mean Score } & \multicolumn{2}{c}{ Standard Deviation } & \multirow{2}{*}{$\begin{array}{c}\text { Gained of } \\
\text { Mean Score }\end{array}$} \\
\cline { 2 - 5 } & Pretest & Posttest & Pretest & Posttest & \\
\hline Experimental & 29.15 & 45.77 & 9.27 & 10.25 & 16.62 \\
\hline Control & 66.88 & 67.54 & 9.85 & 7.48 & 0.73 \\
\hline
\end{tabular}

The table above shows that the mean score of experimental group and control group is different. Both of the group gets higher mean score on posttest than their pretest score. Both of the mean score and standard deviation are different.

It also shows that the difference of the mean score of pretest and posttest of experimental group is 16.62 while control group is 0.73 . It means that $\overline{X_{A}}>$ $\overline{X_{B}}(16.62>0.73)$. The students of experimental group get better improvement than the students' of control group. Thus, it can be concluded that the hypothesis was tenable.

Besides using those kinds of descriptive statistics above, the hypothesis is also tested by using t-test statistical analysis. In order to know whether or not students' gained score of both groups is statistically different at the level of significance 0.05 with degree of freedom $(\mathrm{df}=\mathrm{n} 1+\mathrm{n} 2-2) 50$, where $\mathrm{n}$ is number of subject, the result of calculation can be seen underneath.
Table 3. The t-test of the Students' gained score

\begin{tabular}{ccc}
\hline Variable & $\begin{array}{c}\text { t-test } \\
\text { value }\end{array}$ & t-table value \\
\hline Gained Score & 2.65 & 2.021
\end{tabular}

The table 3 shows that the t-test value of gained score (2.65) was higher than ttable value (2.021). Thus, the hypothesis was tenable.

\section{CONCLUSION}

Based on the results above, it can be concluded that using jigsaw listening can improve the students listening comprehension. It is proved by the gained of the mean score. The experimental group gets better improvement score than the control group does (16.62>0.73). Besides, the result of gained score of the t-test shows that the t-test value is greater than ttable $(2.65>2.021)$. Accordingly, the hypothesis was tenable and it means that 
there is a significant improvement of students' listening comprehension who are taught by using jigsaw listening.

\section{REFERENCES}

[1] Atmaranie. (2011). The Use of Jigsaw Method to Create PAIKEM situation for Students of the $X$ Grade in SMAN 2 Parepare. Thesis UNM.

[2] Baso, F.A. (2011). The Implementation of JIGSAW Method to Enhance English Speaking Skill of the Eight Year Students of SMPN 1 Takalar. Thesis UNM.

[3] Depdiknas.2005. Peraturan Direktorat Jenderal Pendidikan Dasar dan Menengah tentang Penilaian Perkembangan Anak Didik. Jakarta: Dirjen Dikdasmen.

[4] Eka. F. (2011). Implementating JIGSAW Technique to Improve Students Reading Comprehension at SMAN 16 Makassar. Thesis UNM.

[5] Fitri. (2011). The Implementation of Jigsaw Method in Improving the Students' Speaking Skill. Thesis UNM.

[6] Gay, L.R. (2006). Educational Research (Eighth Edition).
Colombus: Hell and Howell Company.

[7] Harmer, J.(2007). How to Teach English. London: Longman Group

[8] I Ismail, U Jabri, R Rahmat, M Musdalifah (2017) Rubrics-Based Assessment as a Teaching Strategy of Writing Journal for Novice Authors. INTERNATIONAL CONFERENCE ON EDUCATION.

[9] Rost, M. (2002).Teaching and Researching Listening. London, UK: Longman.

[10] Villareal, A. (2012). Math, Science still taught the old school way. Retrieved on December, $10^{\text {th }}, 2012$ from $h t t p: / / w w w$. Youtube.com/voalearningenglish

[11] Vilareal, A. (2012). War in Syria Stays out of Damascus Spice Market. Retrieved on

[12] December, 10 $10^{\text {th }}, 2012$ from http://www.

Youtube.com/voalearningenglish

[13] Wipf, J. (1984). Strategies for Teaching Second Language Listening Comprehension. Retrieved on March, $13^{\text {rd }}, 2012$ from http://www.llas.com/listening 